\title{
Regional Heat Capacity and Surface Temperature Changes Due to Oil Palm Plantation Development on 1994-2010 Based on Landsat-5 TM Satellite Data
}

\author{
Idung Risdiyanto $^{1) *}$, Winda Aryani ${ }^{1)}$, Odjat Sujatnika ${ }^{2)}$ \\ ${ }^{1)}$ Department of Geophysic and Meteorology, Bogor Argicultural University, Bogor-Indonesia; \\ winda.aurorarayani@gmail.com \\ 2)Aksenta, Sosio-Environment Consultant, Jakarta-Indonesia; odjat@aksenta.com \\ *Correspondence: idungris@ipb.ac.id
}

\begin{abstract}
Regional heat capacity change is calculated from the ratio between the addition or subtraction of heat $(\Delta \mathrm{Q})$ with the increase or decrease in temperature $(\Delta \mathrm{T})$ region. The purpose of this study is to calculate the regional heat capacity change due to the changes of land cover composition with forest, shrubs, oil palm plantation and bare soil using Landsat-5 TM satellite data on 1994, 2000 and 2010. Total area that used on this study is 12971 ha. In 1994-2000, $4 \%$ of forest area and 2\% shrubs were increased, followed by additional of biomass forest 4.01 tons/ha and 2.83 tons/ha for shrubs. The increased of forest area and biomass (tons/ha) caused by forest and shrubs growth processing towards climax that added the canopy volume. So that, the regional heat capacity in 1994 amounted $19384 \mathrm{MJC}^{\mathrm{o}-1}$ increased to $19929 \mathrm{MJC}^{0-1}$ in 2000. Data observation for 2000-2010 showed that forest area decreased by $66 \%$ due to forest's clearing into oil palm plantations (47\%), shrubs (8\%) and bare soil (11\%). But, plant's biomass continue to increased, i.e 1.48 ton/ha for forest, 2.73 tons/ha for shrubs and 4.63 tons/ha for bare soil. Before 2000, there was no land cover by oil palm plantations, so the increasing rate from this land was the biggest than the three other lands, amounting to 122.29 tons/ha. Decreasing in the percentage of forest area does not cause a decrease in the heat capacity of the region. Intensive maintenance on oil plam plantation such as water management, fertilizer and planting space made it biomass productivity and ability to save the heat is greater than the forest. As the result, in 2010 regional heat capacity increased to $22508 \mathrm{MJC}^{0-1}$.
\end{abstract}

Keywords: Albedo; Biomass; Land cover; Regional heat capacity; Surface Temperature

\section{Introduction}

The utilization of forests for settlements, settlements, mines and plantations in Indonesia began intensively since 1970. Deforestation during the period 1985-1997 has covered about 20 million ha. Sumatra and Kalimantan are the areas with the largest deforestation of 6.7 million ha and 8.5 million hectares (Holmes, 2002). The forest area has been reduced from 103.33 million hectares to 88.17 million hectares in the period of 2000-2009, in Kalimantan about 4.95 million hectares and Sumatra 3.33 million hectares (Sumargo et al., 2011). In 1984-1998 there were approximately 2.4 million hectares of forest converted to oil palm plantations, mainly in Kalimantan and Sumatra. The area of oil palm plantations increased from 4.16 million hectares in 2000 to 8.25 million hectares in 2009 (The Ministry of Agriculture of Indonesia, 2009)

Land cover changes have been impacted to surface albedo values so that the ability of the earth's surface to absorb, reflect and forward the coming solar radiation also changes. The albedo value is influenced by the type and nature of surface radiation, atmospheric conditions, 
as well as the physical properties of surfaces such as colour, water content and surface roughness (Dobos, 2003). This results in changes in surface energy balance and heat capacity, thus affecting the spatial distribution of microclimate elements, such as surface temperatures.

Multispectral remote sensing data such as Landsat TM can be used to estimate surface temperature changes due to urban area expansion and land cover changes. Weng et al. (2001) showed that urban growth increased surface temperature by $13.01 \mathrm{~K}$ and positively correlated with decreasing plant biomass marked by changes in vegetation index. Weng et al. (2004) also estimated the surface temperature of vegetation and urban areas by the vegetation index approach and found that there was a negative correlation between surface temperature and vegetation index of -0.73 for forest and -0.67 for urban. The small vegetation index shows low vegetation and biomass densities. Changes in surface temperature and vegetation biomass of a region will affect the heat capacity of the region, namely the ability of the region to store energy derived from solar radiation.

The purpose of this study was to calculate the change in heat capacity due to changes in the composition of the cover area as a result of land conversion to oil palm plantations in the period 1994-2010. The approach used is the surface energy balance method and temperature change using Landsat-5 TM remote sensing satellite data. This data is used because Landsat-5 TM provides the longest data series based on satellite observation so it can be used as a resource to monitor the earth on a global scale and see the effect of land change on the value of the region's heat capacity.

\section{Methods}

\section{Satellite imagery correction and intepretation}

The study area is $112^{\circ} 24^{\prime} 29^{\prime \prime}-112034^{\prime} 1$ "BT and $2^{\circ} 30^{\prime} 54^{\prime \prime}-2037^{\prime} 37^{\prime \prime} L S$ which is administratively located in Seruyan district and Kotawaringin Timur, Central Kalimantan. The topography of the study area ranges from $0-150 \mathrm{mdpl}$, with most of the area is lowland, swamp and slightly hilly area in the North. This study uses Landsat 5 TM Path / Row 119/62 data, the date of acquisition of 1 September 1994, 9 March 2000 and 16 January 2010 (USGS, 2014). The data management and analysis process uses some software such as Minitab 15, ER Mapper 7.1 and Arc Map 10.0 (No. IPB License: EFL588104064). The considerations used in using different data months of the acquisition are clean data with low levels of resistance. In addition, the values of the three data analyzes are not to be compared.

The data analysis procedure consists of preparing satellite image data, calculating energy balance component, biomass calculation and heat capacity calculation area. Preparation of image data processing starts from geometric correction, taking of study area and classification of land cover. Geometric correction is done to reduce the geometry error so that the image projection matches the map (Jensen, 2000). The classification of land cover is done by unclassified classification method, which is the process of grouping the digital number (DN) image into several classes using cluster analysis (Indarto and Faisol, 2009).

Classification of land cover class consists of forests, shrubs, oil palm plantations and open land. Using a composite band 542 Landsat 5 TM for vegetation (USGS, 2013). This composite image can detect and distinguish visual image capture by placing it on three primary colors (red green blue, RGB) in sequence. Band 5 captures mid-infrared waves $(1.567-1.784 \mu \mathrm{m})$ that are sensitive to reflections of rock and soil moisture. Band 4 captures the near infrared wave $(0.776-0.904 \mu \mathrm{m})$ that is sensitive to the reflection of the leaf's internal structure so it can be 
used to determine the biomass content, vegetation type and area with high vegetation reflections. Band 2 captures green waves $(0.528-0.609 \mu \mathrm{m})$ sensitive to fertility and reflection of green vegetation values, sediment concentration estimators and bathymetry mapping (EROS Data Center, 1995).

\section{The surface energy balance components}

All Landsat $5 \mathrm{TM}$ satellite image data is DN in 8 bits format which must be converted to spetral radiance (Wm-2sr-1) with equations from USGS (2013). The channels used include (i) the visible spectral channel (band 1,2,3) used in the energy balance calculations to obtain shortwave EM radiation and albedo, (ii) Red and NIR channels (bands 3 and 4) to calculate NDVI and (iii) thermal channel (band 6) for surface temperature $\left(\mathrm{Ts},{ }^{0} \mathrm{C}\right)$.

Albedo $(\alpha)$ is the ratio of reflected solar radiation (Rs out) to the coming radiation (Rs in) on an object on the surface (Stull, 2000) and has a range of values $0-1$. The value $\alpha=0$ indicates that the object absorbs all radiation Short wave that comes, while $\alpha=1$ indicates the object reflects entirely. Albedo is a function of wavelength, so its value gives physical information that occurs at the wavelength.

The surface temperature is the outermost temperature of an object. The surface temperature was extracted from Landsat-5 TM band 6-thermal (wavelenght range are 10.45-12.42 $\mu \mathrm{m}$ ). Band 6 can detect natural phenomena related to heat so that it can be used for mapping and thermal geological information (EROS Data Center, 1995). The temperature of the image data extraction result is the brightness temperature that is converted from the spectral radiance value with the assumption that the surface of the earth is black (emissivity =1) (Chander et al. 2009), so it is necessary to do the emissivity correction with NDVI approach. According to Artis and Carnahan (1982), Ts is a function of $\mathrm{Tb}$ (brightness temperature) and emissivity ( $\varepsilon$ ) objects ((vegetation 0.96, open land 0.95) (Jin \& Liang 2006, Van De Griend \& Owe 1993)), and wavelength $(\Lambda)$ emission radiation $(11.5 \mu \mathrm{m})$ with the following equation (eq.1):

$$
\mathrm{Ts}=\frac{\mathrm{T}_{\mathrm{B}}}{\left(1+\frac{\lambda \mathrm{T}_{\mathrm{B}}}{\partial} \ln \varepsilon\right)}
$$

An energy balance approach was conducted to obtain a net radiation value (RN, watt.m-2). It was the difference between the in and out coming (longwave and shortwave) radiation of the earth's surface system by the following equation:

$$
\begin{aligned}
& \mathrm{RN}=\mathrm{Rs} \text { in }- \text { Rs out }-\mathrm{RL} \text { out } \\
& \mathrm{RN}=\mathrm{G}+\mathrm{H}+\mathrm{LE}
\end{aligned}
$$

The value of incoming shortwave radiation from the equation $\alpha=\frac{R s \text { out }}{R s \text { in }}$ (eq.4), albedo ( $\alpha$ ) is calculated by the USGS (2013) equation and the RL out value is derived from the StefanBoltzman equation.

Allen et al. (2001) calculated soil heat flux (G, watt.m-2), from RN, Ts, $\alpha$ and Normalized Difference Vegetation Index (NDVI), as:

$$
\frac{\mathrm{G}}{\mathrm{Rn}}=\frac{\mathrm{Ts}}{\alpha}\left(0.0038 \alpha+0.0074 \alpha^{2}\right)\left(1-0.98 \mathrm{NDVI}^{4}\right) \quad \text { (eq.5) }
$$

where, 


$$
\mathrm{NDVI}=\frac{(\mathrm{NIR}-\mathrm{Red})}{(\mathrm{NIR}+\mathrm{Red})}
$$

Furthermore, $H$ is calculated by eq. 3 and bowen ratio $\beta=\frac{H}{L E}$ (eq.7), so the equation is obtained $\mathrm{H}=\frac{\beta\left(\mathrm{R}_{\mathrm{n}}-\mathrm{G}\right)}{1+\beta}$ (eq.8); $\beta$ of tropical forest $=0.47$ and $\beta$ of palm plantations $=0.29$ (Fowler 2011), $\beta$ of shrubs $=0.93$ (Fisch et al. 2001), and $\beta$ of open forestland $=0.4$ (Oliver 1973). The LE was calculated as the remaining energy of Rn (eq.3).

After all the energy balance components are known, the air temperature $\left(\mathrm{Ta},{ }^{0} \mathrm{C}\right)$ can be calculated by modifying the Monteith \& Unsworth equation (1990), as:

$$
\mathrm{Ta}=\mathrm{Ts}-\left(\frac{\left.\mathrm{Hr}_{\mathrm{aH}}\right)}{\rho_{\mathrm{air}} \mathrm{C}_{\mathrm{p}}}\right)
$$

Humid air density $\left(\rho_{\text {air }}\right)$ is $1.27 \mathrm{~kg} \cdot \mathrm{m}^{-3}$, specific heat of air at constant pressure $\left(\mathrm{c}_{\mathrm{p}}\right) 1004 \mathrm{~J} . \mathrm{Kg}^{-}$ ${ }^{1} \mathrm{~K}^{-1}$. The aerodynamic resistance $\left(\mathrm{r}_{\mathrm{aH}}\right)$ is calculated by the formula $\mathrm{r}_{\mathrm{aH}}=31.9 \cdot \mathrm{u}^{-0.96}(\mathrm{u}=$ normal wind speed at altitude $1-2 \mathrm{~m}, \mathrm{u}$ vegetation $=1.41 \mathrm{~m} \cdot \mathrm{s}^{-1}$ and $\mathrm{u}$ non-vegetation $=1.79 \mathrm{~m} \cdot \mathrm{s}^{-1}$ ) (Rosenberg, 1974) .

\section{Regional heat capacity}

The regional heat capacity is the ability of an area to store the heat received from solar radiation. The common approach of heat capacity is obtained from the product of the specific heat to the mass of the object, since information on the heat of the type of land cover does not exist, the regional heat capacity in this study is calculated by the ratio of heat changes $(\Delta \mathrm{Q})$ to the temperature changes $(\Delta \mathrm{T}), \mathrm{C}=\frac{\Delta \mathrm{Q}}{\Delta \mathrm{T}}($ eq.10)

\section{Result}

\section{Land cover changes and Albedo ( $\alpha$ )}

Forest area increased by 4\% from 1994 to 2000, it was came from bush and shrubs succession to the forest. Open land in 1994 also has occurred a succession to the bush and shrubs. As a result, in the year 1994-2000 the extent of bush cover increased 2\% and open land area decreased 6\%. In 2010 the forest area was reduced by 66\%, which changed to oil palm plantations $(47 \%)$, shrubs $(8 \%)$, and open land (11\%), leaving only $4 \%$ of the total area covered. Part of the open land in 2000 was the result of forest and bush conversion that was suspected as a preparation for oil palm plantations (Figure 1).
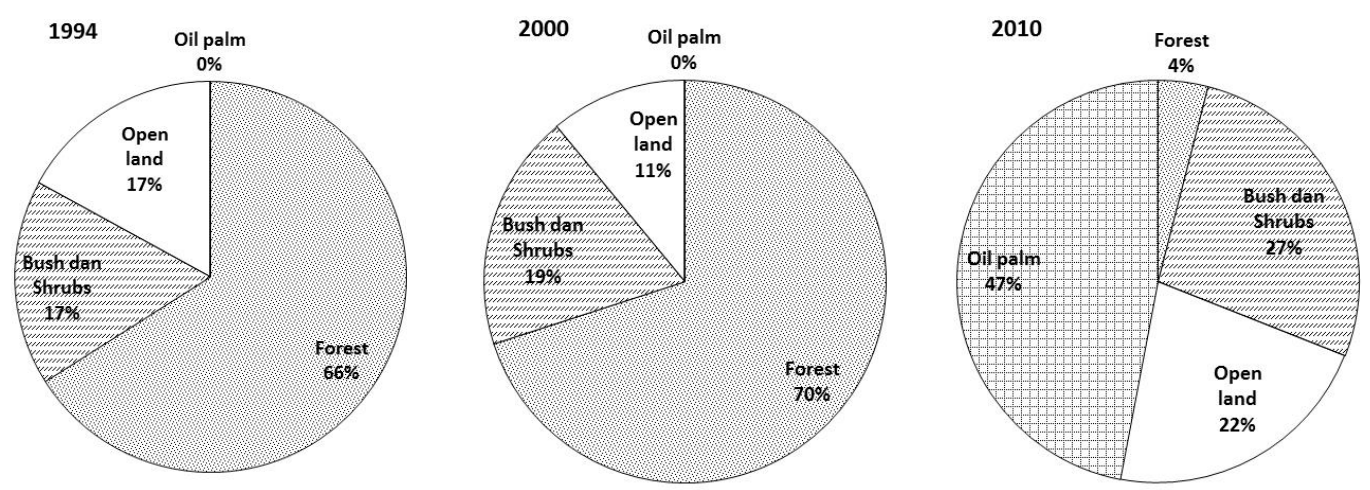

Figure 1. Area percentage of each type of land cover from Landsat-5 TM image interpretation

Land cover changes since 1994, 2000 and 2010 led to a change in the of solar radiation balance received by the surface. The value of Rs in for all types of land cover tends to be the same, 
which is $765-766 \mathrm{~W} \cdot \mathrm{m}^{-2}$ for $1994,799-801 \mathrm{~W} \cdot \mathrm{m}^{-2}$ for 2000 , and $804-806 \mathrm{~W} \cdot \mathrm{m}^{-2}$ for 2010 . Rs out each type of cover is different, oil palm $\left(52.9 \mathrm{~W} . \mathrm{m}^{-2}\right)$, forests $(53-66 \mathrm{Wm}-2)$, bush and shrubs $\left(62-72 \mathrm{~W} \cdot \mathrm{m}^{-2}\right)$ and open land $\left(70-79 \mathrm{~W} \cdot \mathrm{m}^{-2}\right)$. The Rs out value of each land cover in different years can not be compared because of the difference in solar radiation reception time corresponding to the date of satellite image acquisition.

Radiation parameters on the surface that can be compared to land cover are $\alpha$ values. Oil palm plantation cover is the smallest compared to others, ie 0.07 , forest-ie $0.07-0.08$, bush and shrubs ie 0.08-0.09, and open land has the largest albedo with a range of 0.09-0.10 (Table 1). Changes in land cover types from 1994 to 2010 were not significant because the conversion of forest land is still used for vegetated land cover, so the change in albedo value from year to year is not large. This indicates that the land cover of palm oil plantations that absorb more homogeneous solar radiation compared to others.

The range of albedo extraction of image data in this study is still within the range of albedo previous research results, so that the results obtained can describe albedo in the study area. The distribution of albedo values from 1994, 2000 and 2010 shows lower (Figure 2). The mean albedo values at the regional level are $0.090,0.089$ and 0.086 respectively. This condition means that in 2010, the proportion of the amount of solar radiation reflected in 2010 is smaller than in previous years. It also shows that in 2010 more surface absorbs incoming solar radiation.

Table 1. Albedo values extracted Landsat-5 TM satellite image data and references

\begin{tabular}{|c|c|c|c|c|c|c|c|}
\hline \multicolumn{4}{|c|}{ Albedo from satellite data } & \multicolumn{4}{|c|}{ Albedo reference } \\
\hline Land cover type & 1994 & 2000 & 2010 & \multicolumn{2}{|c|}{ Vegetation cover } & \multicolumn{2}{|c|}{ Tutupan non-vegetasi } \\
\hline forest & 0.08 & 0.08 & 0.07 & Bush and Shrubs* & $0.06-0.08$ & $\operatorname{Road}^{* *}$ & $0.05-0.20$ \\
\hline Bush and shrubs & 0.09 & 0.09 & 0.08 & Grassland $* * * *$ & $0.10-0.25$ & Roof** & $0.08-0.18$ \\
\hline Open land & 0.1 & 0.1 & 0.09 & Mix forest $* * * *$ & $0.05-0.20$ & Soil $* *$ & $0.05-0.40$ \\
\hline Oil palm & & & 0.07 & Oil palm * & $0.05-0.07$ & Bare soil $* * *$ & $0.07-0.11$ \\
\hline Keterangan: & $\begin{array}{ll}* & : \mathrm{R} \\
* * & : \mathrm{O}\end{array}$ & $\begin{array}{l}\text { yanto } \\
1987\end{array}$ & Setiaws & In (2007) & $\begin{array}{l}* * * \\
* * * *\end{array}$ & $\begin{array}{l}\text { st et al. }(2000) \\
\text { bos }(2003)\end{array}$ & \\
\hline
\end{tabular}

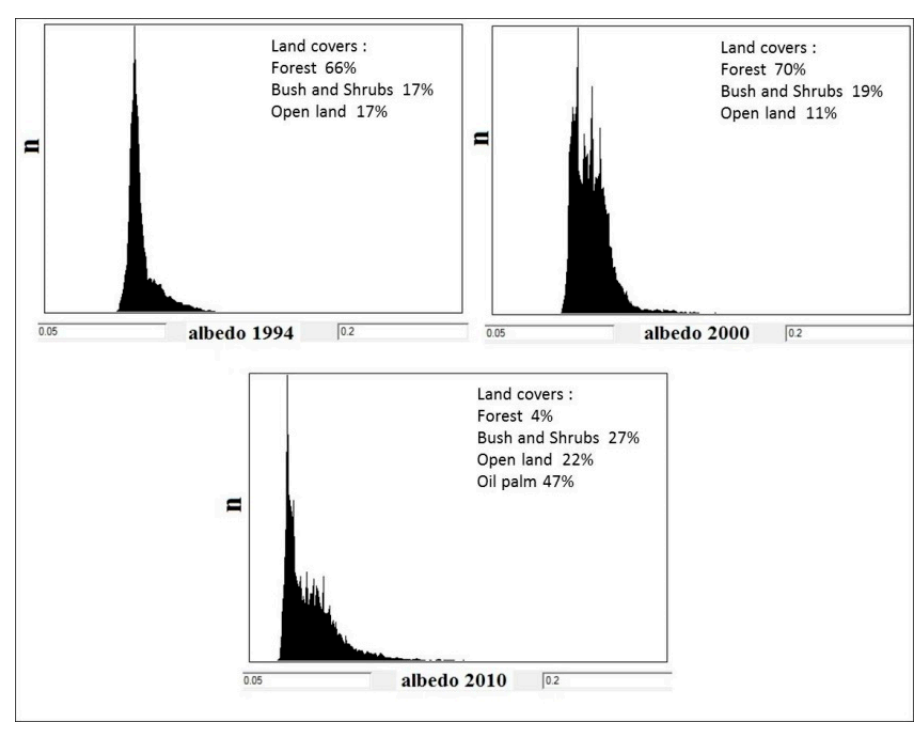

Figure 2. Distribution of albedo values in 1994, 2000 and 2010 
6

\section{Spatial distribution of surface temperature}

The surface temperature distribution of Landsat-5 TM data extraction results in 1994, 2000 and 2010 is presented in Figure 3. The average surface temperature shows a decrease, as well as its deviation. The change in surface temperature in this area is the impact of changes in the area and composition of land cover in the study area. Each land cover has different emissivity, conductivity and heat capacities. The higher density level of vegetation cover, it will cause the lower surface temperature. This is in accordance with the results of research by Weng et al. (2004) using NDVI to denote vegetation density and stated that the surface temperature is negatively correlated with NDVI.

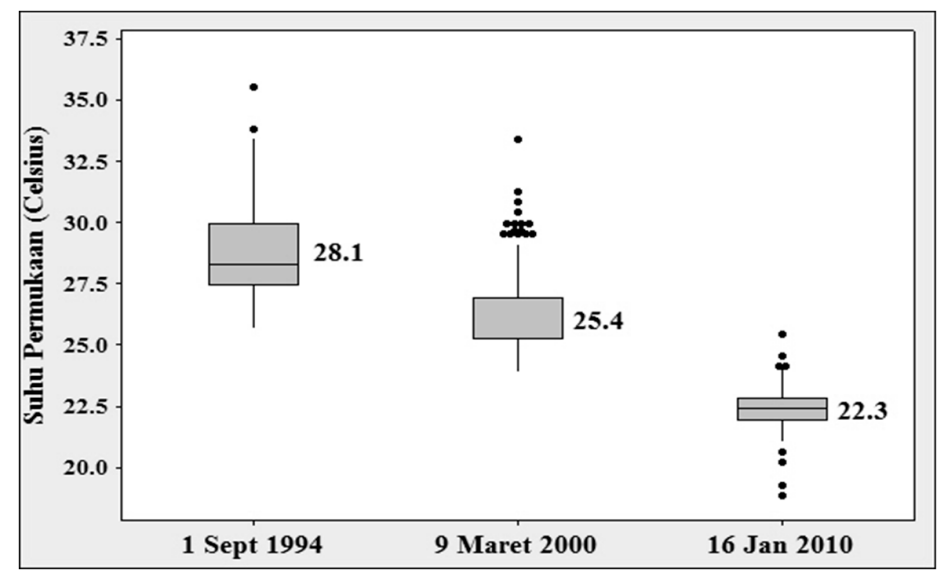

Figure 3. The surface temperature range in the study area with Landsat-5 TM satellite data

\section{Surface Energy Balance}

The common pattern of net radiation is inversely proportional to albedo and surface temperature (Ts). The higher value of the albedo and surface temperature, the smaller the radiation will be. Net Radiation ranging from the largest is oil palm cover, forests, shrubs and open land. The calculation results show that the value of $\mathrm{H}$ is inversely proportional to $\mathrm{LE}$ (Table 2). The $\mathrm{H}$ ranging value from the largest is in open land, shrubs, forests and oil palm plantations. In contrast, the LE score of the largest is found in oil palm plantations, forests, shrubs and open fields.

$\mathrm{H}$ value is the energy used for surface heating. The higher H-to-R ratio can show more heat flux near the surface (Figure 4). The distribution of ratios between $\mathrm{H}$ and $\mathrm{Rn}$ for the whole region shows that in 2010 had a lower average value compared to the year 1994 and 2000. The addition of forest and forest area from 1994 to 2000 increased the ratio to $43.1 \%$ and $42.6 \%$, while conversion to palm oil decreased the ratio to $36.2 \%$.

Table 2 Spatial distribution of energy balance of each land cover with Landsat-5 TM satellite image data

\begin{tabular}{lccccccccccccc}
\hline \multirow{2}{*}{ Land cover } & \multicolumn{3}{c}{$\mathrm{RN}\left(\mathrm{W} . \mathrm{m}^{-2}\right)$} & \multicolumn{3}{c}{$\mathrm{G}\left(\mathrm{W} . \mathrm{m}^{-2}\right)$} & \multicolumn{3}{c}{$\mathrm{H}\left(\mathrm{W} . \mathrm{m}^{-2}\right)$} & \multicolumn{3}{c}{$\mathrm{LE}\left(\mathrm{W} . \mathrm{m}^{-2}\right)$} \\
\cline { 2 - 13 } & 1994 & 2000 & 2010 & 1994 & 2000 & 2010 & 1994 & 2000 & 2010 & 1994 & 2000 & 2010 \\
\hline Forest & 257 & 303 & 339 & 28.8 & 30.8 & 27.2 & 73.1 & 87.0 & 99.9 & 155.5 & 185.1 & 212.5 \\
Bush and shrub & 251 & 295 & 327 & 29.1 & 31.1 & 28.6 & 106.8 & 127.2 & 144.0 & 114.8 & 136.8 & 154.9 \\
Open land & 236 & 282 & 322 & 31.4 & 34.3 & 31.0 & 163.9 & 197.8 & 233.2 & 41.0 & 49.5 & 58.3 \\
Oil palm & & & 340 & & & 25.8 & & & 70.6 & & & 243.3 \\
\hline
\end{tabular}




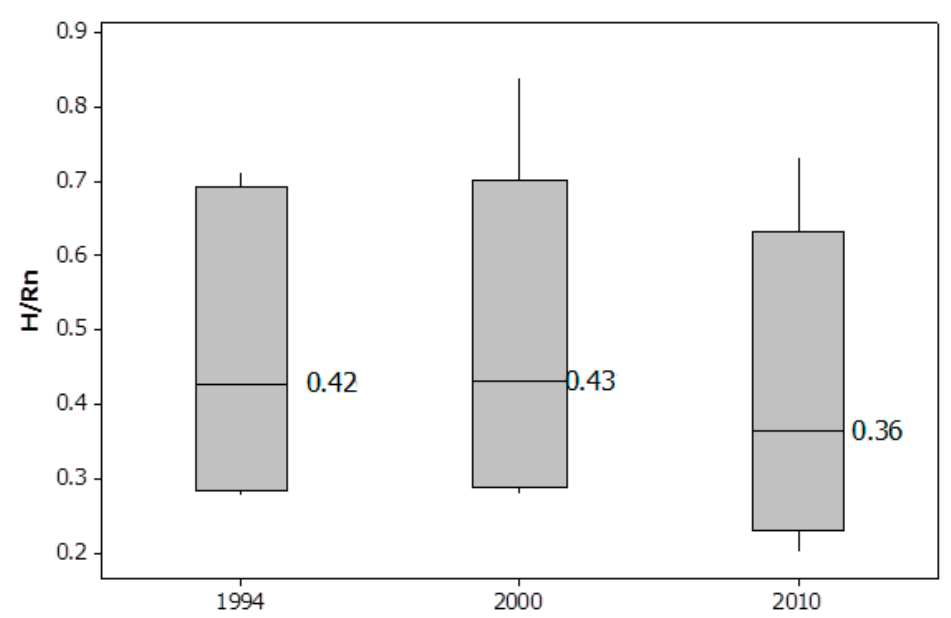

Figure 4. Changes in the ratio of $\mathrm{H}$ to $\mathrm{Rn}$ in the study area

\section{Regional Heat Capacity}

The resulting heat capacity value illustrates the amount of instantaneous energy contained in the study area on changes in air temperature and surface temperature. The heat capacity of each type of land cover varies (Figure 5). When viewed from the type of land cover, the largest heat capacity is found in oil palm plantations because only with a percentage of $47 \%$ of the total area can store the heat of $14991 \mathrm{MJ}^{\circ} \mathrm{C}^{-1}$ close to 1994 forest heat capacity value of $14929 \mathrm{MJ}^{\circ} \mathrm{C}^{-}$ ${ }^{1}$ whose percentage is $66 \%$ Of the study area. The heat capacity of shrubs and open land is almost the same because although the land cover is classified as open land, its NDVI ranges from $0.35-0.44$, meaning that on open ground vegetation is still encountered in the form of grass that is sufficient to withstand heat.

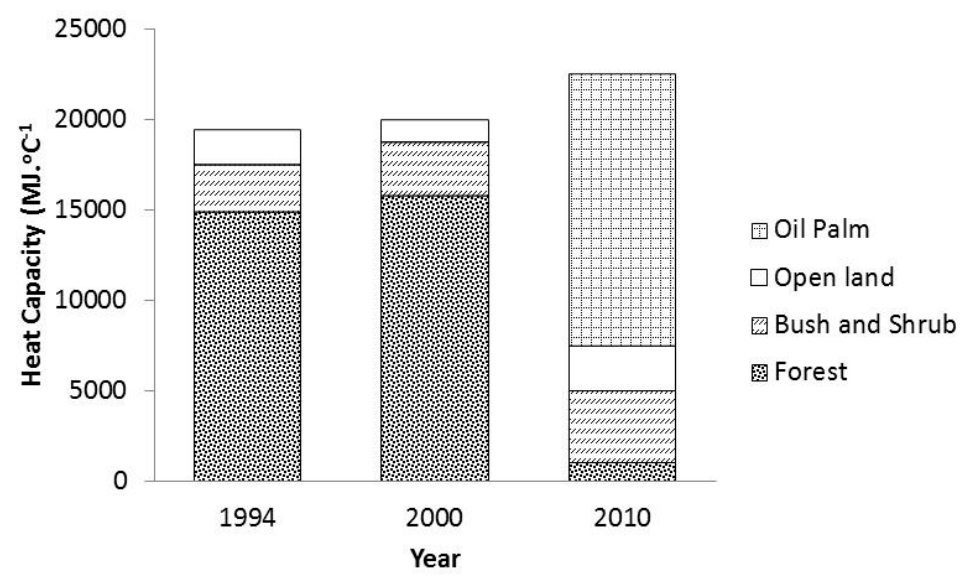

Figure 5. The heat capacity of each type of land cover with Landsat-5 TM

During the period of 1994-2010, there was an increase in regional heat capacity. In 1994, the regional heat capacity was $1494 \mathrm{kJC}^{0-1} \mathrm{Ha}^{-1}, 2000$ was $1536 \mathrm{kJC}^{0-1} \mathrm{Ha}^{-1}$ and in 2010 was 1738 $\mathrm{kJC}^{\mathrm{o}-1} \mathrm{Ha}^{-1}$ (Figure 6). The increase between 1994-2000 was caused by the addition of forest area by $4 \%$ and $2 \%$ shrubs. While in 2000-2010 caused by conversion of forest land into palm oil plantation by $47 \%$. Oil palm plantations in 2010 have better heat storage capabilities than shrubs, forests and open land. 


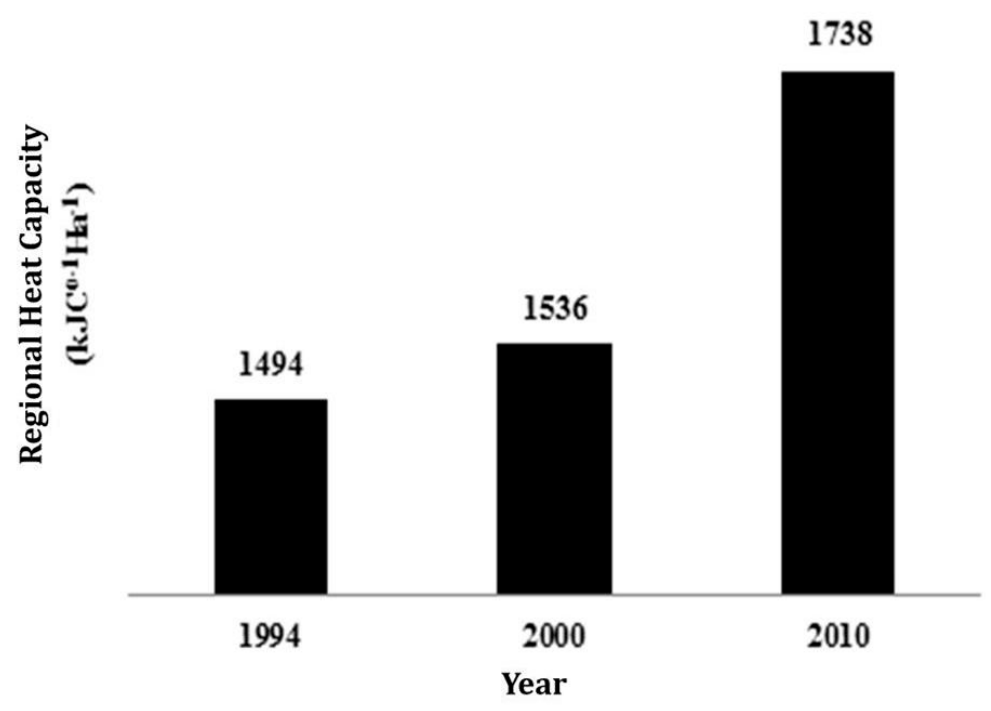

Figure 6. Changes in regional heat capacity of the study area per hectare with Landsat-5 TM

\section{Discussions}

The albedo values of each land cover type vary due to differences in surface physical properties such as vegetation fraction, water content, surface color and roughness (Geiger et al, 1961; Wei et al., 2001). The soil albedo is determined by particle size, mineral composition, moisture, organic matter content and surface roughness. Dobos (2003) adds that the surface of a subtle object is capable of reflecting greater radiation than a rough surface. Small albedo values in vegetated land cover are also caused by multilevel canopies that can absorb solar radiation at multiple levels of the canopy (Peng et al, 2015). That is, when the coming solar radiation is reflected back by the leaves / stems of plants in diffuse, canopy levels and canopy plant at the bottom of the canopy can absorb back the radiation.

Evaluation of albedo value according to the physical properties of the surface that influence it, indicating this value can be used as one of the indicators to know the change of regional heat capacity. Smaller albedo values are caused by changes in the land cover composition area, where oil palm plantations and forests absorb more incoming solar radiation than shrubs and bareland.

The difference in acquisition date of satellite data causes the surface temperature value to be incommensurable. Data for 1994 and 2000 were taken on September 1 and March 9 when the relative position of the sun was around the equator, while January 16, 2010 was in the vicinity of the subtropics. Weng et al. $(2001,2004)$ also explained that the difference in solar radiation illumination in image data can affect the value of surface temperature. However, differences in the land cover composition will obviously affect the distribution of surface temperatures (Yan et al, 2014). Therefore, in this study comparable absolute value of the deviation between the mean surface temperature of the region with the surface temperature of each pixel (30x30 m2). In addition, relating to surface temperature can also be compared is the ratio between $\mathrm{H}$ with Rn and with LE. Steward et al., (1994); Braam, (2008) and Miglietta et al., (2009) mentioned that the surface temperature correlates with heat flux whose value is affected by the object or the type of surface. 
The absolute value of the difference between the surface temperature of the region and the mean temperature shows that in 2010 showed the lowest deviation value compared to 1994 and 2010. Ts deviation for the entire study area were $1.3^{\circ} \mathrm{C}, 1.4^{\circ} \mathrm{C}$ and $0.7^{\circ} \mathrm{C}$ for 1994,2000 and 2010. Ts value of each land cover indicates that secondary forest and oil palm plantations have a lower value than other land cover. This shows that climate conditions in 2010 are more stable and cooling. Runnall and Oke (2006) use the daily maximum and minimum temperature differences to determine the cooling ratio.

The land cover change to vegetated land causes more incoming solar radiation to be absorbed by the surface (Gao and $\mathrm{Wu}, 2014$ ), so net radiation also increases. The energy of the net radiation reaching the earth's surface is then used for the process of soil heat flux $(\mathrm{G})$, sensible heat flux $(\mathrm{H})$, latent heat flux (LE) and residual energy used for metabolic processes of organisms (S ). According to Sellers (1965), the value of residuals for terrestrial areas can be neglected as it is very small. The value of $\mathrm{G}$ is derived from the equation of Allen et al. (2001), where $\mathrm{G}$ is directly proportional to Ts, so the energy for warming the soil on open land will be greater than the vegetated land.

Open land has a small LE value because of its high conductivity and shortwave reflection. Net radiation in open land is mostly used for heating the air so that the energy stored for the evapotranspiration process is low. By contrast, vegetated land has lower shortwave reflections and thermal conductivity (Bett, 2001; Soto et al., 2015) so that the LE is larger. Much of the net energy on the surface is used for evapotranspiration and less for heating air. Oil palm plantations have the highest LE of all vegetation cover as there is a water treatment system that is able to retain moisture around the plantation. Vegetation land cover with high LE values has low surface temperature values. This is due to the proportion of the sensible heat flux that may cause a smaller temperature rise (Handoko et al., 1994). The increase in $\mathrm{H}$ value is an indication of ongoing heating process and vice versa for cooling (Molotch, 2010). This proves that the condition of 2010 experiencing surface cooling.

One of the factors affecting the area heat capacity in this research is potential biomass, ie the mass that comes from converting solar energy into organic material through photosynthesis process. Biomass is also affected by net radiation ( $\mathrm{Rn} 2010>\mathrm{Rn} 2000>\mathrm{Rn} 1994)$, where the greater the solar energy that can be used for the photosynthesis process, the potential biomass to be produced is also greater.

The calculation of the heat capacity value will give better results if using the function of the object mass and the heat of the object type. However, this study has not been conducted because there is no information on the types of forest cover, bushes, oil palm and open land. In addition, the calculation of biomass in any land cover is also not done. Therefore, the heat capacity calculation is based solely on the ratio of the addition or reduction of heat $(\Delta \mathrm{Q})$ to the increase or decrease in temperature $(\Delta \mathrm{T})$. The weakness of heat value calculation by using Landsat-5 TM image data is the time of repeat image coverage (the time required for satellite image to photograph the same coordinate and path / row object) is 16 days. In addition, geographically the territory of Indonesia is located around the path of ITCZ (Inter Tropical Convergence Zone), which is the area with intensive air lifting process that causes high levels of resistance that can scatter the coming solar radiation.

\section{Conclussions}

Changes in land cover composition in the study areas in 1994, 2000 and 2010 led to an increase in regional heat capacity. Increased forest area by 4\% and 2\% shrub in 1994-2000 year, 
increasing the region's heat capacity increased by $3 \%$. Oil palm plantations covering $47 \%$ of the study area in 2010 could increase the region's heat capacity by $11.5 \%$ compared to 2000 . Increased regional heat capacity from 1994, 2000 and 2010 led to a smaller range of surface temperature values in the study area in the addition of heat or energy Which comes from solar radiation.

Increased heat capacity in a region can be used as an indication of cooling in the context of climate change on a regional scale. The absorption of solar radiation is increasing with increasing heat capacity. One factor that is thought to increase heat capacity is to increase the rate of growth that can increase the amount of biomass on the surface.

\section{References}

Allen RG, Morse A, Tasumi M, Bastiaansen W, Kramber W, Anderson H. 2001. Evapotranspiration from Landsat (SEBAL) for water right management and compliance with multi-state water compact. University of Idaho Kimberly, ID 83341

Artis DA \& Carnahan WH. 1982. Survey of emissivity variability in thermography of urban areas. J Remote Sens. Environ. 12: 313-329.

Betts RA. 2001. Biogeophysical impacts of land use on present-day climate: near-surface temperature change and radiative forcing. Atmospheric Science Letters (2001) Volume 1. doi:10.1006/asle.2001.0023

Chander G, Markham BL, Helder DL. 2009. Summary of current radiometric calibration coefficients for Landsat MSS, TM, ETM+ and EO-1 ALI sensors. J Remote Sens. Environ. 113(2009):893-903. doi:10.1016/j.rse.2009.01. 007.

[Deptan] Departemen Pertanian. 2009. Basis data statistik pertanian [internet]. [diacu 2012 Desember 6]. Tersedia dari: http://aplikasi.deptan.go.id/bdsp /newlok.asp.

Dobos E. 2003. Albedo. Encyclopedia of Soil Science. doi:10.1081/E-ESS 120014334.

Domingo F, Villagarcia L, Brenner AJ, Puigdefabregas J. 1999. Evapotranspiration model for semi-arid shrub-lands tested against data from SE Spain. $J$ Agricultural and Forest Meteorology.95(1999):67-84.

EROS Data Center. 1995. Landsat-7 Technical Working Group. Sioux Falls, USA South Dakota. October 31-November 2, 1995.

Fisch G, Tota J, Machado LAT, Dias MAFS, Lyra RF da F, NobreCA, Dolman AJ, Culf AD, Halverson J and Fuentes JD. 2001. The convective boundary layer over pasture and forest in Amazonia. Aerospace Technical Center, Institute of Aeronautics and Space, University Sao Jose dos. Brazil.

Fowler D, Nemitz E, Misztal P, Marco CD, Skiba U, Ryder J, Helfter C, Cape JN, Owen S, Dorsey $\mathrm{J}$ et al. 2011. Effects of land use on surface-atmosphere exchanges of trace gases and energy in Borneo: comparing fluxes over oil palm plantations and a rainforest. $J$ Environ. Science. 366:3196-3209. doi:10.1098/rstb.2011.0055.

Gao J and Wu S. 2014. Simulated effects of land cover conversion on the Surface energy budget in the southwest of China. Energies 2014, 7, 1251-1264; doi:10.3390/en7031251

Garbulsky MF, Peñuelas J, Papale D, Ardö J, Goulden ML, Kiely G, Richardson AD, Rotenberg E, Veenendaal EM and Filella I. 2010. Patterns and controls of the variability of radiation use efficiency and primary productivity across terrestrial ecosystems. $J$ Macroecology. 19:253-267. doi: 10.1111/j.1466-8238.2009.00504.x 
Geiger R, Aron RH, Paul T. 1961. The Climate Near The Ground. Ed ke-5. Cambridge : Harvard University Press.

Handoko, Abujamin AN, Tania J, Rini H. 1994. Klimatologi Dasar: Landasan Pemahaman Fisika Atmosfer dan Unsur-unsur Iklim. Edisi ke-2. Jakarta (ID): Pustaka Jaya.

Hildanus. 2005. Pendugaan beberapa parameter tegakan hutan tropika dataran rendah menggunakan data satelit landsat (studi kasus di hutan lindung G. Beratus, Kalimantan Timur). Makalah Falsafah Sains (PPs 702). Program Pascasarjana. IPB Bogor

Htut TM. 2004. Combination between emperical modelling and remote sensing technology in estimating biomass and carbon stock of oil palm (in Salim Indoplantation Riau Province) [tesis]. Bogor: Sekolah Pascasarjana IPB.

Holmes DA. 2002. Where Have All the Forest Gone?. Environmental and Social Development East Asia and Pasific Region Discussion Paper. The World Bank.

Imanto H. 2000. Model simulasi dinamika nitrogen pada pertanaman kelapa sawit (Elaeis guineensis Jacq.) [skripsi]. Bogor: Departemen Geofisika dan Meteorologi, FMIPA, Institut Pertanian Bogor.

Indarto \& Faisol A. 2009. Identifikasi dan klasifikasi peruntukan lahan menggunakan Citra ASTER. J Media Teknik Sipil. 9(1):1-8. ISSN: 1412-0976

Jensen JR. 2000. Remote Sensing of the Environment: An Earth Resource Perspective. New Jersey: Prentice Hall.

Jin M and Liang S. 2006. An improved land surface emissivity parameter for land surface models using global remote sensing observations. J Climate. 19:2867-2881.

Monteith JL and Unsworth MH. 1990. Principles of Environmental Physics. 2nd ed. London: Edward Arnold

Nouvellon Y, Seen DL, Rambal S, Begue A, Moran MS, Kerr Y and Qi J. 2000. Time course of Radiation Use Efficiency in a shortgrass ecosystem: consequences for remotely sensed estimation of primary production. J Remote Sens. Environ. 71:43-55. New York: Elsevier Science Inc.

Oke TR. 1987. Boundary Layer Climates. 2nd ed. Methuen, London, England and New York, NY,USA, $452 \mathrm{pp}$.

Oliver JE. 1973. Climate and Man's Environment: An Introduction to Applied Climatology. New York: John Wiley \& Sons, Inc.

Pangle L, Vose JM and Teskey RO. 2008. Radiation use efficiency in adjacent hardwood and pine forests in the Southern Appalachians. $J$ Forest Ecology and Management. 257(2009):1034-1042. doi:10.1016/j.foreco.2008.11.004

Peng J, Fan W, Xu X, Wang L, Liu Q, Li J, and Zhao P. 2015. Estimating crop albedo in the application of a physical model based on the law of energy conservation and spectral invariants. Remote Sens. 2015, 7, 15536-15560; doi:10.3390/rs71115536

Post DF, Fimbres A, Matthias AD, Sano EE, Accioly L, Batchily AK dan Ferreira LG. Predicting Soil Albedo from Soil Color and Spectral Reflectance Data. J Applied Meteorology. 64(3):1027-1034. doi: 10.2136/sssaj2000.6431027.

Risdiyanto I dan Setiawan R. 2007. Metode neraca energi untuk perhitungan indeks luas daun menggunakan data citra satelit multi spektral. J Agromet Indonesia. 21 (2) : 27 - 38.

Rosenberg NJ. 1974. Microclimat: The Biological Environment. New York: John Willey and Sons 
Schneider N dan Eugster W. 2006. Climatic impacts of historical wetland drainage in Switzerland. Springer Science and Business Media B.V. Switzerland.

Sellers WD. 1965. Physical Climatology. The University of Chicago Press, Chicago, 60637.

Soto NS, Cueto RG, Rincón ZH, Benítez SO, Núñez MQ, and Limón NV. 2015. Radiation balance of urban materials and their thermal impact in semi-desert region: Mexicali, México study case. Atmosphere 2015, 6, 1578-1589; doi:10.3390/atmos6101578

Stull RB. 2000. Meteorology for Scientists and Engineers. 2nd ed. USA. Brooks/Cole, Cengange Learning. Brooks/Cole, Cengage Learning, Belmont, CA, USA, 528 pp

Sumargo W, Nanggara SG, Nainggolan FA, Apriani I. 2011. Potret Keadaan Hutan Indonesia Periode Tahun 2000-2009. Edisi Ke-1. Forest Watch Indonesia.

Turner DP, Cohen WB, Kennedy RE, Fassnacht, Briggs JM. 1999. Relationships between Leaf Area Index and Landsat TM Spectral Vegetation Indices across Three Temperate Zone Sites. J Remote Sens. Environ. 70:52-68. New York: Elsevier Science Inc.

Twele A, Erasmi S dan Martin K. 2006. Estimation Leaf Area Indexunder Dense Kanopi Conditionsusing Hemispherical Photographyand Optical Earth Observation Data: Prediction Capabilities of Spectral Indices and Artifical Neural Networks. Gottingen : Workshop STORMA.

[USGS] United State Geological Survey. 2013. Landsat 7 science data users handbook [internet]. [diacu 2013 Februari 20]. Tersedia dari: http:// landsathandbook.gsfc.nasa.gov/pdfs/Landsat7_Handbook.pdf .

Van De Griend AA and Owe M. 1993. On the relationship between thermal emissivity and the normalized difference vegetation index for nature surfaces. Int. J. Remote Sens. 14:11191131.

Wei X, Hahmann AN, Dickinson RE, Yang ZL, Zeng X, Schaudt KJ, Scaaf CB and Strugnell N. 2001. Comparison of albedos computed by land surface models and evaluation against remotely sensed data. Journal of Geophysical Research. Vol,106, No.D18:20687-20702

Weng Q. 2001. A remote sensing - GIS evaluation of urban expansion and its impact on surface temperature in the Zhujiang Delta, China. Int. J. Remote Sens. 22(10) : 1999-2014.

Weng Q, Lu D, Schubring J. 2004. Estimation of land surface temperature- vegetation abundance relationship for urban heat island studies. J Remote Sens. Environ. 89 (2004): 467-383. doi:10.1016/j.rse.2003.11.005

Yan H, Fan S, Guo C, Hu J, Dong L (2014) Quantifying the Impact of Land Cover Composition on Intra-Urban Air Temperature Variations at a Mid-Latitude City. PLoS ONE 9(7): e102124. https://doi.org/10.1371/journal.pone.0102124

Zhang X and Kondragunta S. 2006. Estimating forest biomass in the USA using generalized allometric models and MODIS land products. Geophysical Research Letters. Vol. 33,L09402, doi:10.1029/2006GL025879. 